\title{
Endocrine-disrupting organochlorine xenobiotics in fish products imported from Asia-an assessment of human health risk
}

\author{
Agata Witczak (D) Daiki Harada • \\ Aleksandra Aftyka $\cdot$ Jacek Cybulski
}

Received: 19 July 2020 / Accepted: 26 January 2021 / Published online: 16 February 2021

(C) The Author(s) 2021

\begin{abstract}
The sources of endocrine-disrupting persistent organochlorine compounds (OC) are environmental pollutants. Contaminated food is a direct result of environmental pollution, and fish are considered as the main source of OC in the human diet. This study aimed to analyze the contamination of imported fish fillets with organochlorine pesticides (OCPs) and polychlorinated biphenyl (PCB) congeners in the context of potential health risks of consumers in Poland in the light of the new tolerable weekly intake (TWI) values. The tested compounds in fish products were determined by liquid-liquid extraction and gas chromatography mass spectrometry (GS-MS) method. Despite the detection of almost all pesticides analyzed in the fish fillets tested, the risk factor (hazard quotient) was significantly lower than 1.0, ranging from 0.003 to 0.013 . Considering the previous
\end{abstract}

A. Witczak $(\square) \cdot$ A. Aftyka $\cdot$ J. Cybulski

Department of Toxicology, Dairy Technology and Food Storage, Faculty of Food Sciences and Fisheries, West Pomeranian University of Technology, Szczecin, Poland e-mail: agata.witczak@zut.edu.pl

A. Aftyka

e-mail: ola.aftyka@wp.pl

J. Cybulski

e-mail: jacek.cybulski@zut.edu.pl

D. Harada

Laboratory of Regulation of Metabolism and Behavior,

Faculty of Agriculture, Kyushu University,

Fukuoka 819-0395, Japan

e-mail: daiki_0117_0328@yahoo.co.jp recommended TWI value (14 pg-TEQ/kg bw/week), the estimated weekly intake was lower at $43-53 \%$ of TWI. However, according to the new TWI values set by the EFSA in 2018, the estimated weekly intake was about three times higher than the TWI. This raises concerns regarding threats to consumer health.

Keywords Imported fish products · Endocrinedisrupting compounds · Organochlorine pesticides . Polychlorinated biphenyls · Assessment of human health risk

\section{Introduction}

In recent years, persistent organic pollutants (POPs) have been the focus of great concern partly because of the toxic effects induced by organochlorine compounds. The most important were the organochlorine pesticides (OCPs) that were used commonly in agricultural production process and, i.e., mosquito control in the twentieth century. Polychlorinated biphenyls (PCBs) were applied widely in many industries, particularly in electrotechnics (EFSA, 2005; Faroon \& Ruiz, 2016). The characteristics of these compounds are similar regarding their extreme persistence, good solubility in fat, and high bioaccumulation in living organisms (Barr et al., 2007; Salem et al., 2009; Lagalante et al., 2009; Walczak $\&$ Reichert, 2016). Both groups of these compounds 
were considered persistent organic pollutants (POPs) (Stockholm Convention, 2018).

These compounds have been shown to exhibit mainly estrogenic and mutagenic or partly carcinogenic properties in animals (Gregoraszczuk et al., 2003). Organochlorine xenobiotic residues are often detected in foods, and especially in fish products (Deribe et al., 2014; Cui et al., 2015). Due to the specific physico-chemical properties of the organochlorine compounds (OC), the frequent consumption of contaminated fish can increase the health risk of consumers.

Fish and seafood are considered healthier alternatives to meat and meat products. According to FAO, in 2010-2015, the global production of fish and other aquatic organisms increased 15\% from 147 to 168.7 million tonnes (World aquaculture, 2010; FAO, 2018). The OECD-FAO estimated that, in 2017-2026, fish consumption in the EU will increase by about 5\% thanks to the ongoing economic recovery and changes in the nutrition trends of Europeans (OECD/FAO, 2017).

Based on the chemical structure of OCPs, the main groups include chloroethylene hydrocarbons; dichlorodiphenyls-DDT, and methoxychlor; cyclodienic derivatives-aldrin, dieldrin, heptachlor, endosulfan, and chlordan; cycloparaffinic derivatives- $\mathrm{HCH}$ and lindane; and chlorinated terpenes-toxaphene. The presence of harmful compounds -particularly the most durable metabolite of DDT (p,p'DDE), the hexachlorocyclohexane isomer $(\beta-\mathrm{HCH})$, and HCB is evident in all environmental samples and in materials derived from human beings worldwide.

On the other hand, there are 209 individual congeners of PCBs, which include non-dioxin-like PCBs (ndl-PCBs) and dioxin-like PCBs (dl-PCBs including mono-ortho and non-ortho congeners). These compounds differ in their properties and toxic effects on the human body.

It is well known that PCB congeners are characterized by high bioaccumulation rates in aquatic organisms, including fishes (Chang, 2018).

Fishes are now seen as a health-promoting dietary component since they are sources of wholesome protein and provide a number of vitamins and microelements, but above all they contain polyunsaturated fatty acids (PUFA), n-6 and n-3, especially EPA and DHA.
The efficacy of n-3 highly unsaturated fatty acids, principally EPA and DHA, in the prevention or modulation of many inflammatory conditions prevalent in the developed world is well established. However, there is concern that POP contamination (e.g., dioxins, PCBs, or PBDEs) and the presence of toxic metals (e.g., $\mathrm{Pb}, \mathrm{As}, \mathrm{Cd}$, and $\mathrm{Hg}$ ) present potential risks to human health (Bell and Waagb $\varnothing, 2008$; Guo et al., 2019).

China is currently the world's largest exporter of fishery products. Along with many other European countries, Poland imports large quantities of Chinese fishes and fish products that are purchased by a wide range of consumers because of their relatively low prices. The most common species imported to Poland are Nile tilapia (Orechromis niloticus niloticus), panga (Pangasius pangasius), Pacific cod (Gadus macrocephalus), pollock (Pollachius virens), and yellowfin sole (Limanda aspera). The volume of Polish imports is estimated to be approximately 260,000 tonnes of frozen fish fillets and fish products annually, which places Poland at the top of European importers (Euszczek-Trojnar et al., 2015). Because of the scale of its fishery product exports, it is crucial to note that China was the world's largest producer of OCPs and PCBs between 1945 and 1983. According to recent Chinese investigations, both OCPs and PCBs are still detected in the environment and in food products (Huang et al., 2019; Zeng et al., 2014).

Based on IARC/WHO (2016), PCBs are still found as posing real threats. This is evidenced by the 2016 change in the classification of dl-PCBs to group 1 compounds that are carcinogenic to humans (IARC/ WHO, 2016), and the EFSA (2018) lowered the TWI value seven-fold from 14 to $2 \mathrm{pg}-\mathrm{TEQ} / \mathrm{kg}$ b.w./week.

The aim of our study was to analyze the content of organochlorine compounds (OCPs, ndl-PCBs, dlPCBs including mono-ortho and non-ortho congeners) in imported fish fillets and to assess the potential risk to Polish consumer health according to the new TWI values.

\section{Materials and methods}

\section{Sampling}

The research material was collected from batches of frozen fillets without skin in glazes of five species of 
fish-Nile tilapia (Orechromis niloticus niloticus), panga (Pangasius pangasius), Pacific cod (Gadus macrocephalus), pollock (Pollachius virens), and yellowfin sole (Limanda aspera) mainly imported from China and Vietnam obtained in 2017-2018. Individual batches of fillets (the number of batches for each fish species are in Table 1) came from different producers (the list of producers is known to the authors) and differed in the quantity of glaze (according to manufacturer declarations). The glaze is a protective layer of water added to the surface of frozen seafood. Each batch weighed about $2.5 \mathrm{~kg}$. A total of $790 \mathrm{sam}-$ ples, 10 from each batch, were tested.

\section{Analytical methods and instrumentation}

Samples from the frozen batches of glazed fish fillets were delivered to the Department of Toxicology of the Faculty of Food Sciences and Fisheries, West Pomeranian University of Technology in Szczecin, where they were labeled and stored at $-18{ }^{\circ} \mathrm{C}$ until analysis. Prior to analysis, the fish samples were homogenized and freeze-dried for about $36 \mathrm{~h}$ in a LyoLab 3000-type lyophilizer (temperature $-60^{\circ} \mathrm{C}$ ).

Determinations of the content of the compounds tested were performed on $5 \mathrm{~g}$ of lyophilized samples, each of which was analyzed in triplicate. The analytical procedure in Witczak and Ciereszko (2006) was applied to extract lipids containing OCPs and PCBs, and GC/MS (HP 6890/5973) was used to purify and identify compounds. For extracting the examined compounds together with lipids, a $50-\mathrm{cm}^{3}$ acetone/nhexane solution $(\mathrm{v} / \mathrm{v})(2.5: 1)$ was used each time and again a $50-\mathrm{cm}^{3} \mathrm{n}$-hexane/diethyl ether solution $(\mathrm{v} / \mathrm{v})$ (9:1). The samples were purified by adding fuming
$\mathrm{H}_{2} \mathrm{SO}_{4}\left(7 \% \mathrm{SO}_{3}\right.$ in concentrated $\left.\mathrm{H}_{2} \mathrm{SO}_{4}, \mathrm{w} / \mathrm{w}\right)$. The sample was concentrated to $0.1 \mathrm{~mL}$ under a soft nitrogen flow. Part of the samples was fortified with a known amount of single PCB congeners and pesticides to identify the examined compounds correctly and to determine recovery. Analyses were performed in three replications with the following GC/MS settings: carrier gas-helium; pressure: $0.061 \mathrm{Mpa}$ (8.9 psi); flowrate: $0.8 \mathrm{~mL} \mathrm{~min}{ }^{-1}$, column (HP-5MS, $5 \%$ phenyl methyl siloxane/60.0 m; ID $250 \mu \mathrm{m}, 2.25 \mu \mathrm{m}$ film thickness of the active phase) oven temperature: start from $90^{\circ} \mathrm{C}(0.5 \mathrm{~min})$, increase $7^{\circ} \mathrm{C} \mathrm{min}^{-1} ; 220^{\circ} \mathrm{C}$ (12 min), increase $6^{\circ} \mathrm{C} \mathrm{min}^{-1} ; 285^{\circ} \mathrm{C}(7 \mathrm{~min})$, increase $5{ }^{\circ} \mathrm{C} \mathrm{min}^{-1}$; and $295^{\circ} \mathrm{C}$ (6 min) (post run). The analysis time of one sample was 54.9 min. Detector-mass spectrometer (HP5973).

\section{Procedure evaluation}

The procedure was evaluated according to Witczak (2013) and Tomza-Marciniak et al. (2019).

To test the accuracy of the method, the certified reference material was analyzed for each batch of samples. To correctly identify the tested compounds, some samples were fortified with a known amount of each PCB congener. Mackerel oil (No 350-Community Bureau of Reference, BCR) from Promochem $\mathrm{GmbH}$ was used as reference material. The recovery of PCB congeners from the reference material was in the range of $79.5-91.3 \%$.

The compound recoveries were determined with an internal standard solution of decachlorobiphenyl and 2,4,5,6-tetrachloro-m-xylene in acetone $(100 \mu \mathrm{L}, 80 \mathrm{ppb})$ (Pesticides Surrogate Spike Mix (4-8460, Supelco, USA). Additionally, PCB recoveries were verified using

Table 1 Characteristics of the material tested

\begin{tabular}{llllrr}
\hline Species of fish & $\begin{array}{l}\text { Amount of mate- } \\
\text { rial tested }\end{array}$ & Country of origin & Glaze content, $\%$ & Fat content, \% & Dry weight, $\%$ \\
\hline Nile tilapia & $18^{\mathrm{b}}\left(180^{\mathrm{c}}\right)$ & China & $30.71 \pm 1.89^{\mathrm{a}}$ & $1.39 \pm 0.47$ & $18.39 \pm 1.71$ \\
Panga & $27(270)$ & Vietnam, China & $27.50 \pm 4.63$ & $1.09 \pm 0.73$ & $10.86 \pm 2.19$ \\
Pacific cod & $13(130)$ & China & $27.50 \pm 3.54$ & $0.50 \pm 0.06$ & $16.79 \pm 0.29$ \\
Pollock & $12(120)$ & China & $35.00 \pm 0.00$ & $0.67 \pm 0.09$ & $8.60 \pm 1.42$ \\
Yellowfin sole & $9(90)$ & China & $25.00 \pm 0.00$ & $1.07 \pm 0.17$ & $11.25 \pm 1.13$ \\
\hline
\end{tabular}

\footnotetext{
${ }^{\mathrm{a}}$ Mean \pm standard deviation

${ }^{\mathrm{b}}$ Number of fillet batches

${ }^{\mathrm{c}}$ Number of samples
} 
the addition of a ${ }^{13} \mathrm{C}$-labeled $\mathrm{PCB}$ standard solution $\left({ }^{13} \mathrm{C} 12\right.$-labeled PCB Mixture-A, CIL-Cambridge isotope laboratories, Inc. EC-4938) (3,30,4,40-TetraCB; 3,4,4', $5^{\prime}$-TetraCB; 2',3,4,4',5-PentaCB; 3,3',4,4',5-PentaCB; 3,3',4,4',5,5'-HexaCB; 2,2',3,4,4',5,5'-HeptaCB) $(50 \mu \mathrm{L}, 120 \mathrm{ppb})$. The average recoveries ranged from $71.8 \%$ (PCB 81) to $97.5 \%$ (PCB 180). The recoveries of compounds for which isotopically labeled standards were not available were estimated using the recoveries from samples fortified with the PCB congeners analyzed. The average recovery levels of non-ortho and mono-ortho PCB congeners were PCB 77-80.5\%, PCB 126-69.8\%, PCB 169-88.5\%, PCB 114-74.2\%; PCB 156-81.1\%, PCB $157-83.5 \%$, and PCB 81-77.7\%, while the average recoveries of ndl-PCB congeners (IUPAC No PCB 28, $52,101,138,153,180)$ ranged from 75.2 to $89.8 \%$. The recovery of internal standards ranged from 84.1 to $98.3 \%$. An additional control of the identification and quantification of the analyzed compounds was based on the following standard solutions: (1) 6 PCB-Key Isomers LGC Ltd. NE 5575 (PCB IUPAC: 28, 52, 101, 118, 138, 153); (2) 12 PCB-CERTAN@ NE 5570 LGC Ltd. (IUPAC No PCB 77, 81, 123, 105, 114, 126, 156, 157, 180, 169, 167, 189); and (3) Chlorinated Pesticides Mix-Supelco USA 4-9151 $(\alpha \mathrm{HCH}, \beta \mathrm{HCH}, \gamma \mathrm{HCH}$, heptachlor, aldrin, heptachlor epoxid isomer $\mathrm{B}$, dieldrin, pp'DDE, op'DDD, pp'DDT, pp'DDD, op'DDT, endrin).

The limit of detection (LOD) for each compound was determined as the concentration in the extract that produced an instrumental response to two different ions monitored with a signal to noise ratio of 3:1 for the less sensitive signal (Commission Directive, 2002/63/EC).

A blank method was included for every ten samples. The LOD for each pesticide was $0.01 \mathrm{ng} \mathrm{mL}^{-1}$, on average. The limits of quantification (LOQ) of PCB congeners were $0.03-0.1 \mathrm{ppb}$, and for organochlorine pesticides (OCPs) — as follows: heptachlor epoxide, dieldrin, pp'DDE (0.06 ppb); pp'DDD (0.05 ppb); endrin (0.03 ppb); $\alpha, \beta, \gamma \mathrm{HCH}$, pp'DDT $(0.01 \mathrm{ppb})$; and heptachlor $(0.4 \mathrm{ppb})$. The average recovery of the organochlorine pesticides ranged from 69.8 (endrin) to $98.9 \%$ (pp'DDT).

Statistical testing included determining the arithmetic means of PCBs and OCPs together with standard deviations, SD, medians, and coefficient of variation, $\mathrm{CV}$, analysis of variance (Statistica 13.1 software package), and calculating Pearson's correlation coefficient $(p<0.05)$ and Duncan's significance test $(p<0.05)$.

\section{Hazard quotient}

Estimations of human health risks associated with exposure to chloroorganic pesticides were assessed with the LADD (lifetime average daily dose) Eq. (1) and HQ (hazard quotient) Eq. (2) parameters (Witczak \& Abdel-Gawad, 2014):

LADD (mean daily dosage during life), $\mathrm{mg} / \mathrm{kg} \cdot$ day Eq. (1)

$\mathrm{LADD}=\frac{c \cdot \mathrm{ADC}}{\mathrm{BW}}$

where $C$ is the average concentration of the pesticide in fish; $\mathrm{ADC}$ is the average daily consumption of fish, g/day per person (in Poland $34.30 \mathrm{~g} /$ day) (Hryszko, 2018); and BW is the average body weight (70 kg for an adult), $\mathrm{kg}$.

HQ (hazard ratio) Eq. (2)

$\mathrm{HQ}=\frac{\mathrm{LADD}}{\mathrm{RfD}}$

where RfD is the reference dose $\left(\mathrm{mg} \cdot \mathrm{kg}^{-1} \cdot \mathrm{day}^{-1}\right)$.

An HQ value exceeding 1.0 indicates that it is harmful to human health.

\section{Toxicity equivalency}

TEQ (toxicity equivalency) reports the total toxicity of dioxin-like PCBs. To obtain TEQs, the concentration of each PCB congener in a mixture is multiplied by its toxicity equivalency factor (TEF) Eq. (3), which is established by the WHO (Commission Regulation, (EU) No 1259/2011).

$\mathrm{TEQ}=\sum\left(\left[C_{\mathrm{PCB} i}\right] \cdot \mathrm{TEF}_{i}\right)_{n}$

where $C_{\mathrm{PCB} i}$ is the concentration of $\mathrm{i}-\mathrm{PCB}$ congener.

\section{Statistical analysis}

Statistical analysis conducted with STATISTICA 13.3 included determining the significance of differences with Duncan's test $(p<0.05)$, and the Pearson's correlation coefficients between the lipid and dry matter contents and the compounds analyzed. The mean contents of the compounds, standard deviations, minimum and maximum values, medians, and coefficients of variation were also determined. 


\section{Results}

\section{Organochlorine pesticides}

The present study designated 18 compounds belonging to chloroorganic pesticides in frozen fish fillets imported from China and Vietnam. The results of all compounds are presented as arithmetic averages (in ng/g wet weight) with standard deviation, minimum, maximum, and median values, and coefficients of variation (CV) (Table 2). The lipid content (from 0.32 to $2.08 \%$ ) and dry matter (from 8.08 to $21.19 \%$ ) were determined in the material analyzed, which depended on the amount of glaze used the content of which accounted for between 25 and $35 \%$ of the fish products analyzed (Table 1).

The analysis revealed the presence of almost all pesticides tested in the fish fillets, except for endrin, endrin aldehyde, and heptachlor epoxide isomer B. According to the OCP results, the concentration of $\mathrm{HCH}$ was the highest (Table 2). The content of $\mathrm{HCH}$ isomers differed in different fish species. The highest mean concentrations of $\beta-\mathrm{HCH}, \gamma-\mathrm{HCH}$, and $\alpha-\mathrm{HCH}(0.118 \pm 0.016 \mathrm{ng} / \mathrm{g}$ w.w., $0.222 \pm 0.049 \mathrm{ng} / \mathrm{g}$ w.w., and $0.506 \pm 0.049 \mathrm{ng} / \mathrm{g}$ w.w., respectively) were noted in Nile tilapia (Table 2), and the highest concentration of $\delta-\mathrm{HCH}$ was found in panga $(0.666 \pm 0.149 \mathrm{ng} / \mathrm{g}$ w.w.) (Table 2). No statistically significant differences $(p<0.05)$ were determined in the content of $\mathrm{HCH}$ isomers in Pacific cod, pollock, or yellowfin sole. The content of pp'DDT isomer in Nile tilapia and panga ranged between $0.047 \pm 0.004$ and $0.048 \pm 0.012 \mathrm{ng} / \mathrm{g}$ w.w. No pp'DDT isomers were noted in Pacific cod, pollock, or yellowfin sole. (Table 2). The content of pp'DDE and pp'DDD metabolites differed in all fillets analyzed. The dominant metabolite was pp'DDD with a wet weight concentration ranging from $0.064 \pm 0.007 \mathrm{ng} / \mathrm{g}$ (panga) to $0.138 \pm 0.024 \mathrm{ng} / \mathrm{g}$ (Pacific cod). The highest mean concentration of the pp'DDE isomer was recorded in Nile tilapia and Pacific cod fillets $(0.028 \mathrm{ng} / \mathrm{g}$ w.w.); this differed significantly $(p<0.05)$ compared with the pp'DDE content in the fillets of the other fish species. The lowest concentration of pp'DDE was recorded in panga $(0.019 \pm 0.001 \mathrm{ng} / \mathrm{g}$ w.w. $)$ (Table 2).

Of the five fish species analyzed, the highest average concentration of pesticide residues by wet weight was noted in the Nile tilapia fillets, while the lowest was in the pollock fillets. Particularly noteworthy was that endosulfan sulfate dominated in relation to total endosulfan. This metabolite accounted for $65 \%$ of the total endosulfan in Nile tilapia, 53\% in panga, 73\% in Pacific cod, 55\% in pollock, and $78 \%$ in yellowfin sole. The sulfate form is the only degradation product of endosulfan $\alpha$ and $\beta$ that is considered very toxic. This relationship is also highly stable with a long half-life (2-6 years) depending on environmental conditions. These factors render endosulfan sulfate a more dangerous compound than the parent compound (Shah et al., 2015).

Pearson's correlation coefficient was used $(p<0.05)$ to assess the relationship between the compounds analyzed and the dry matter (\%) and lipid (\%) contents of the fillets tested (Table 3).

Although OCPs are accumulated in adipose tissue, this correlation $\left(r_{\text {w.w. }}=0.033-0.785\right)$ was less pronounced because of the effects of the glaze components that comprised up to $35 \%$ of the product quantity; these included stabilizers (e.g., sodium polyphosphate [E452], pentasodium triphosphate [E452], and calcium polyphosphate [E452]), acidity regulators (e.g., citric acid [E330], sodium citrate [E331], and potassium citrate [E332]), and other additives.

Fish origin had no effect on the content of the compounds analyzed in the fish products tested.

\section{Polychlorinated biphenyls}

As most literature sources report, $90 \%$ of PCBs enter the bodied through the ingestion of contaminated foods, and the largest group of these is foods of aquatic origin (Mamun et al., 2019). Total ndl-PCBs in fish products by wet weight ranged from $0.072 \mathrm{ng} / \mathrm{g}$ to $0.168 \mathrm{ng} / \mathrm{g}$ (Fig. 1a). The highest lipid contents of total ndl-PCBs was detected in Pacific cod at up to $37.45 \mathrm{ng} / \mathrm{g}$ lipids, while the lowest levels were in yellowfin sole and pollock at $14.25 \mathrm{ng} / \mathrm{g}$ (Fig. 1b).

Dl-PCBs can be divided into mono-ortho PCBs and non-ortho PCBs. The content of $\sum$ monoortho PCB ranged from $0.096 \mathrm{ng} / \mathrm{g}$ w.w. in panga to 0.160 ng/g w.w. in Pacific cod (Table 4). The content of $\sum$ non-ortho PCBs ranged from $0.016 \mathrm{ng} / \mathrm{g}$ w.w. to $0.078 \mathrm{ng} / \mathrm{g}$ w.w. The lowest content of these compounds was detected in Nile tilapia and the highest in Pacific cod (Table 4). The content of PCBs in Pacific cod fillets differed significantly compared with that in the other fish products; however, there 


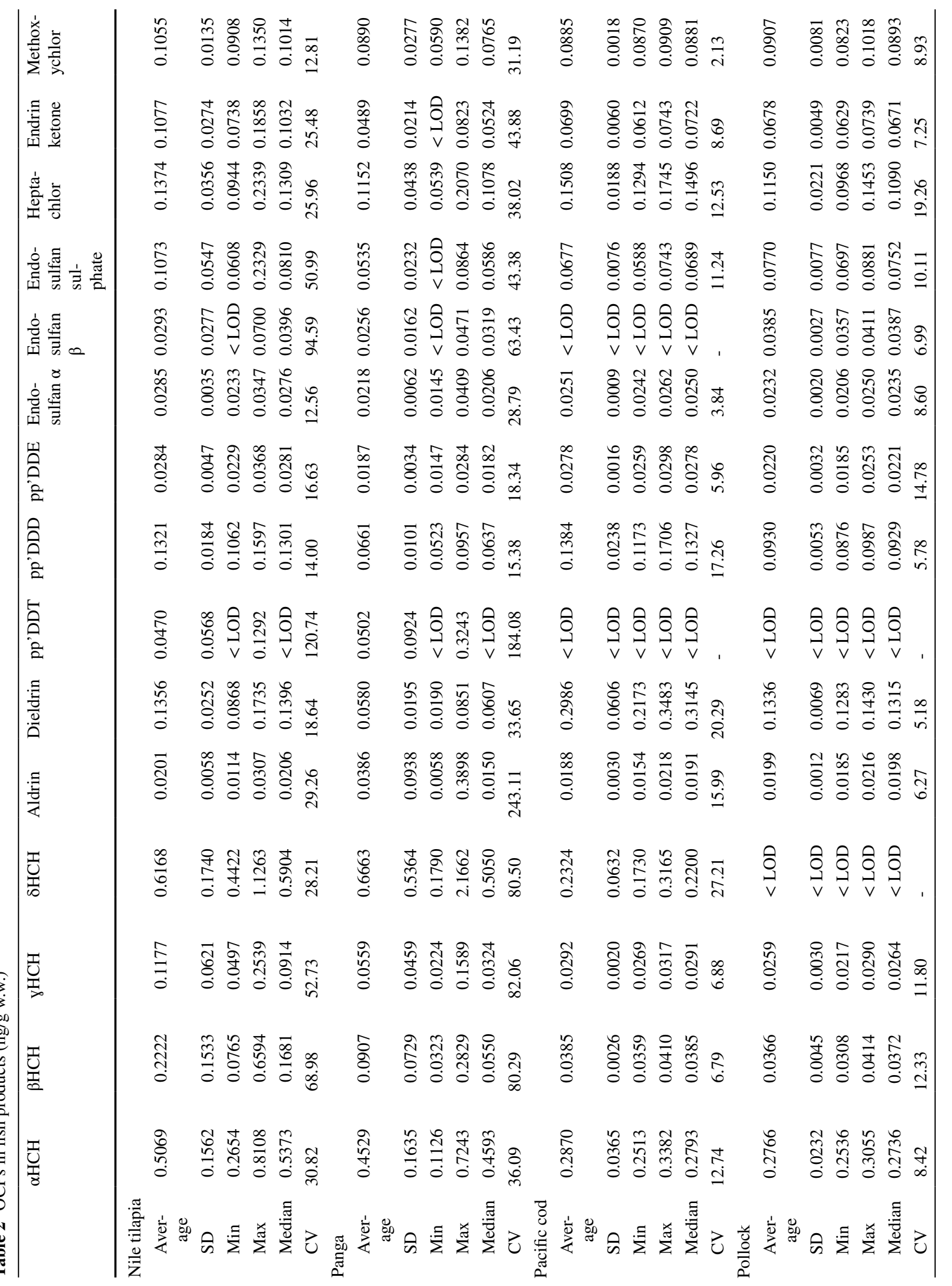


were no significant differences between the contents of individual PCB congeners in Nile tilapia and panga $(p<0.05)$.

Table 3 shows the correlation between the content of the compounds and the dry weight and lipid content of the fish products. Correlation coefficients were determined $(p<0.05)$ to assess the relationships between the substances analyzed and the contents of dry matter and lipids. A strong correlation was only noted between lipids (\%) and PCB 52. The low correlation between the contents of individual PCBs and the lipid content could have resulted from the thick layer of glaze used to prepare the fillets or other additives.

\section{Discussion}

Consuming fish from contaminated environments can have serious consequences for human health. To ensure consumer safety, food products are subjected to regular checks before they reach the market. However, differences in species, origin, or breeding environment can have significant impacts on the final composition of the meat (Mathew et al., 2019). Some example contents of organochlorine compounds in edible fish analyzed in different countries are shown in Table 5.

\section{Health risk assessment of OCPs}

LADD and HQ were the two parameters used in this study to determine consumer exposure to chloroorganic compounds from fish products (Fig. 2). The data obtained indicated that the risk of harmful health effects was low since the HQ hazard ratio ranged from 0.003 to 0.013 . The contaminant concentrations in all samples analyzed in this experiment were also low enough so as not pose any risk to fish or consumer health. However, research from Taiwan showed samples exceeding MRL values for OCPs (Chang 2018). The positivity rate for banned OCPs in the samples from the offshore zone was $6.3 \%$ and that of imported fish was $9.4 \%$. With some exceptions, these estimated daily intake (EDI) values were lower than $1 \%$ of the acceptable daily intake (ADI) established by the Food and Agriculture Organization (FAO) of the United Nations and World Health Organization (Chang 2018). Bioaccumulation in fish 
Table 3 Correlation $(p<0.05)$ between the content of individual OCPs and PCBs and dry weight and lipid contents

\begin{tabular}{|c|c|c|c|c|c|c|}
\hline \multirow[t]{2}{*}{ OCPs } & \multicolumn{2}{|c|}{$\begin{array}{l}\text { Pearson's correlation coefficient, } r \\
(p<0.05)\end{array}$} & \multirow[t]{2}{*}{ PCB congener } & & \multicolumn{2}{|c|}{$\begin{array}{l}\text { Pearson's correlation coefficient, } r \\
(p<0.05)\end{array}$} \\
\hline & With dry mass & With fat content & & & With dry mass & With fat content \\
\hline$\alpha \mathrm{HCH}$ & 0.183 & 0.136 & \multirow[t]{6}{*}{ ndl PCB } & PCB 28 & 0.34 & 0.21 \\
\hline$\beta \mathrm{HCH}$ & 0.671 & 0.393 & & PCB 52 & 0.42 & 0.49 \\
\hline$\gamma \mathrm{HCH}$ & 0.637 & 0,315 & & PCB101 & 0.27 & 0.22 \\
\hline$\delta \mathrm{HCH}$ & 0.033 & 0.026 & & PCB 138 & 0.28 & 0.20 \\
\hline pp'DDT & 0.266 & 0.236 & & PCB 153 & 0.38 & 0.43 \\
\hline pp'DDD & 0.785 & 0.039 & & PCB 180 & 0.21 & 0.37 \\
\hline pp'DDE & 0,778 & 0.191 & \multirow[t]{8}{*}{ Mono-ortho PCB } & PCB 105 & 0.29 & 0.18 \\
\hline Aldrin & 0.090 & 0.071 & & PCB 114 & 0.07 & 0.10 \\
\hline Dieldrin & 0.441 & 0.302 & & PCB118 & 0.03 & 0.29 \\
\hline Endrin ketone & 0.718 & 0.197 & & PCB 123 & 0.17 & 0.15 \\
\hline Heptachlor & 0.445 & 0.087 & & PCB 156 & 0.41 & 0.06 \\
\hline Endosulfan $\alpha$ & 0.635 & 0.297 & & PCB 157 & 0.36 & 0.22 \\
\hline Endosulfan $\beta$ & 0.144 & 0.383 & & PCB 167 & 0.15 & 0.29 \\
\hline Endosulfan sulphate & 0.463 & 0.014 & & PCB 189 & 0.11 & 0.24 \\
\hline \multirow[t]{4}{*}{ Methoxychlor } & \multirow[t]{4}{*}{0.578} & \multirow[t]{4}{*}{0.431} & \multirow[t]{4}{*}{ non-ortho PCB } & PCB 77 & 0.25 & 0.15 \\
\hline & & & & PCB 81 & 0.18 & 0.06 \\
\hline & & & & PCB 126 & 0.32 & 0.23 \\
\hline & & & & PCB 169 & 0.49 & 0.35 \\
\hline
\end{tabular}

is attributed to the residues of OCPs that were used widely globally in the early 1970 s. A recent study in north China indicated that the effect of OCP residuals in atmospheric particulate matter (APM) of farmland regions and aquatic environments could not be ignored since OCP residue levels in APM in certain areas contributed $41.6 \%$ to the already high health risk (Ding et al., 2015). These OCPs in APM could lead to even higher bioaccumulation in the future. Thus, the OCP concentrations in food products, especially those of fish, remain a concern.

\section{Health risk assessment for PCBs}

Many PCBs, which are persistent and predominant in foods, are active as promoters in hepatocarcinogenesis, and lower halogenated biphenyls may be activated metabolically in vivo to genotoxic and initiating intermediates (Ludewig et al., 2008; Faroon \& Ruiz, 2016). According to a report from Sweden, the estimated market basket per capita intake of total PCBs was $4.9 \mathrm{ng} / \mathrm{kg}$ body weight/day, and fish was found to be the major contributor at $64 \%$ (Törnkvist et al., 2011).
Based on EFSA (2018), in group "Fish and seafood" dl-PCB mean content was 21.0-21.6 pg WHO2005$\mathrm{TEQ} / \mathrm{g}$ whole weight. For various fish species, the mean dl-PCB level was 9.17-9.21 pg WHO2005$\mathrm{TEQ} / \mathrm{g}$ whole weight.

Thus, it is necessary to evaluate the concentration of $\sum \mathrm{PCB}$ in fish products and the risk to human and animal health. The TEQ in the fish products, designated as the sum of product concentrations of individual congener TEF toxicities, ranged from $1.79 \mathrm{pg}-$ TEQ/g w.w. in Nile tilapia to 2.14 pg-TEQ/g w.w. in pollock (Fig. 3).

The daily intake of PCBs from consumed fish must be estimated to assess consumer risk. According to the Institute of Agricultural and Food Economics, the annual fish consumption in 2017 in Poland was $12.48 \mathrm{~kg} /$ person, which was a daily intake of $34.19 \mathrm{~g} /$ day/person (Hryszko, 2018). The previous tolerated weekly intake (TWI) was $14 \mathrm{pg}-\mathrm{TEQ} / \mathrm{kg}$ body weight/week or 1-4 pg-TEQ/kg body weight/ day (EFSA, 2015). Based on the results of the current study, the estimated weekly intake (WI) ranged from $6.12 \mathrm{pg}-\mathrm{TEQ} / \mathrm{kg}$ bodyweight/week in Nile tilapia to $7.45 \mathrm{pg}-\mathrm{TEQ} / \mathrm{kg}$ bodyweight/week in pollock, which 
Fig. 1 Content of ndlPCBs in ng/g w.w. (a) and ng/g lipids (b). a-arithmetic mean with standard deviation
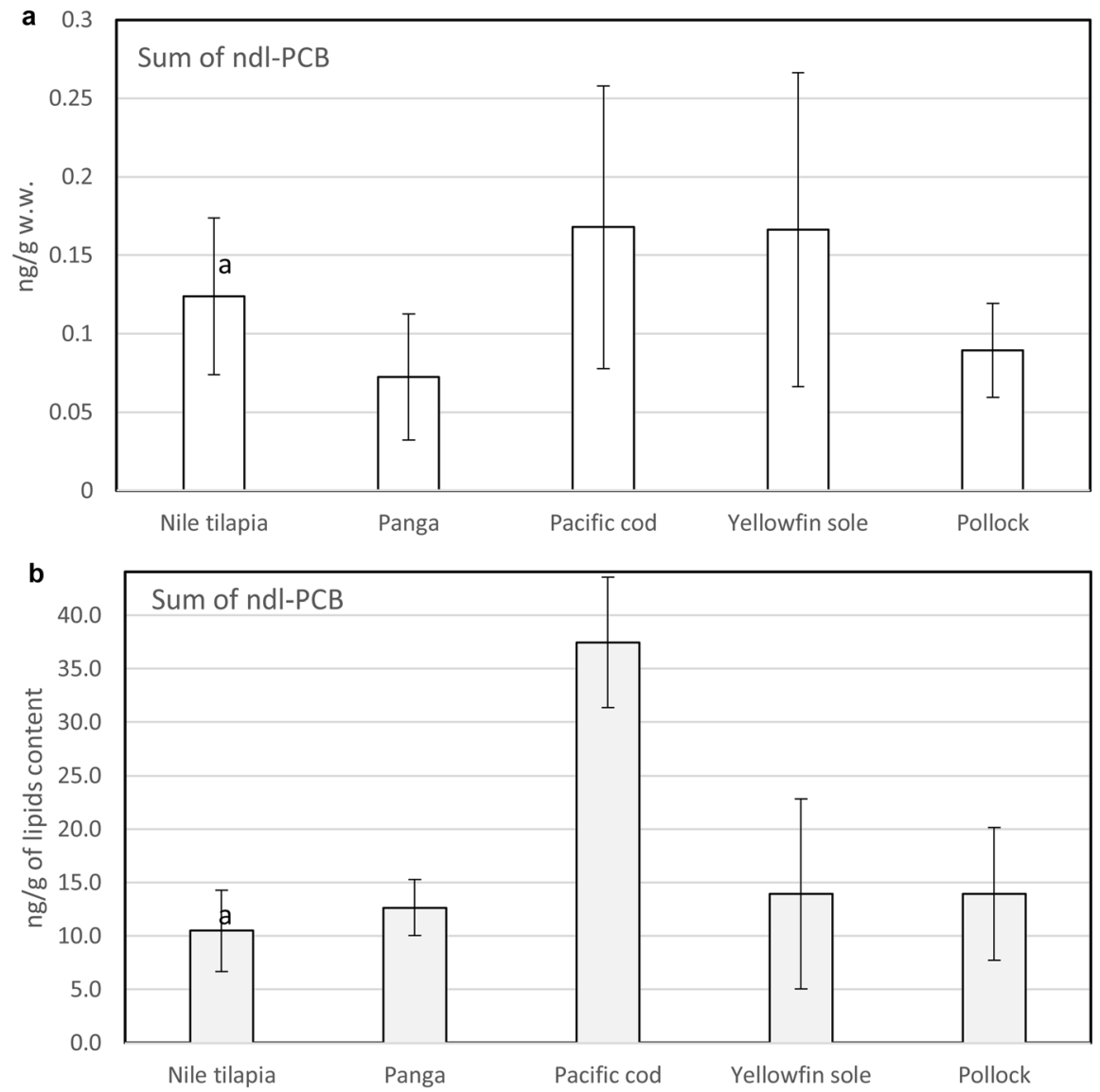

a - arithmetic mean with standard deviation was from 43 to $53 \%$ of the TWI (Fig. 3). The new tolerated weekly intake (TWI) set by the European Food Safety Authority (EFSA Journal, 2018) means that the estimated weekly intake determined in the present study was approximately three times higher than the new TWI value ( $2 \mathrm{pg}-\mathrm{TEQ} / \mathrm{kg}$ body weight/week). This is alarming since these values were obtained using only dl-PCB without dioxins. The decrease in TWI value by the European Food Safety Authority (EFSA Journal, 2018) was intended to increase the consumer safety associated with exposure to PCBs.

Assessing consumer exposure risk through food is weighty and difficult since the actual TEQ should also include toxic compounds such as polychlorinated dibenzo- $p$-dioxins (PCDDs), polychlorinated dibenzo- $p$-furans (PCDFs), and polychlorinated naphthalenes (PCNs). However, polychlorinated biphenyls constitute $>90 \%$ of the total TEQ in fishes (Alcock et al., 1998). Considering the high accumulation of
PCBs, especially non- and mono-ortho congeners in aquatic organisms, as is evidenced by high TEQ toxicity rates in fishes (Ludewig et al., 2008; Lauby-Secretan et al., 2013), the results suggest that the consumer health risk is not too high. On the other hand, research in India showed that fish were highly contaminated with PCBs and posed health threats and lifetime cancer risks to consumers in the city of Hyderabad (Ahmed et al., 2016). According to an investigation by the FAO in 2013, the annual fish consumption in India of $5.8 \mathrm{~kg}$ per capita was similar to that in Poland (Table 6). Fish consumption has been increasing gradually globally since it contains important nutrients like EPA and DHA. Thus, even though the present study showed fish consumption to be low risk, further integrated studies are needed to gain a better understanding of PCB contamination in fish products and PCB exposure that causes health hazards. This is particularly important in the context of EFSA's six-fold reduction in the TWI parameter. 


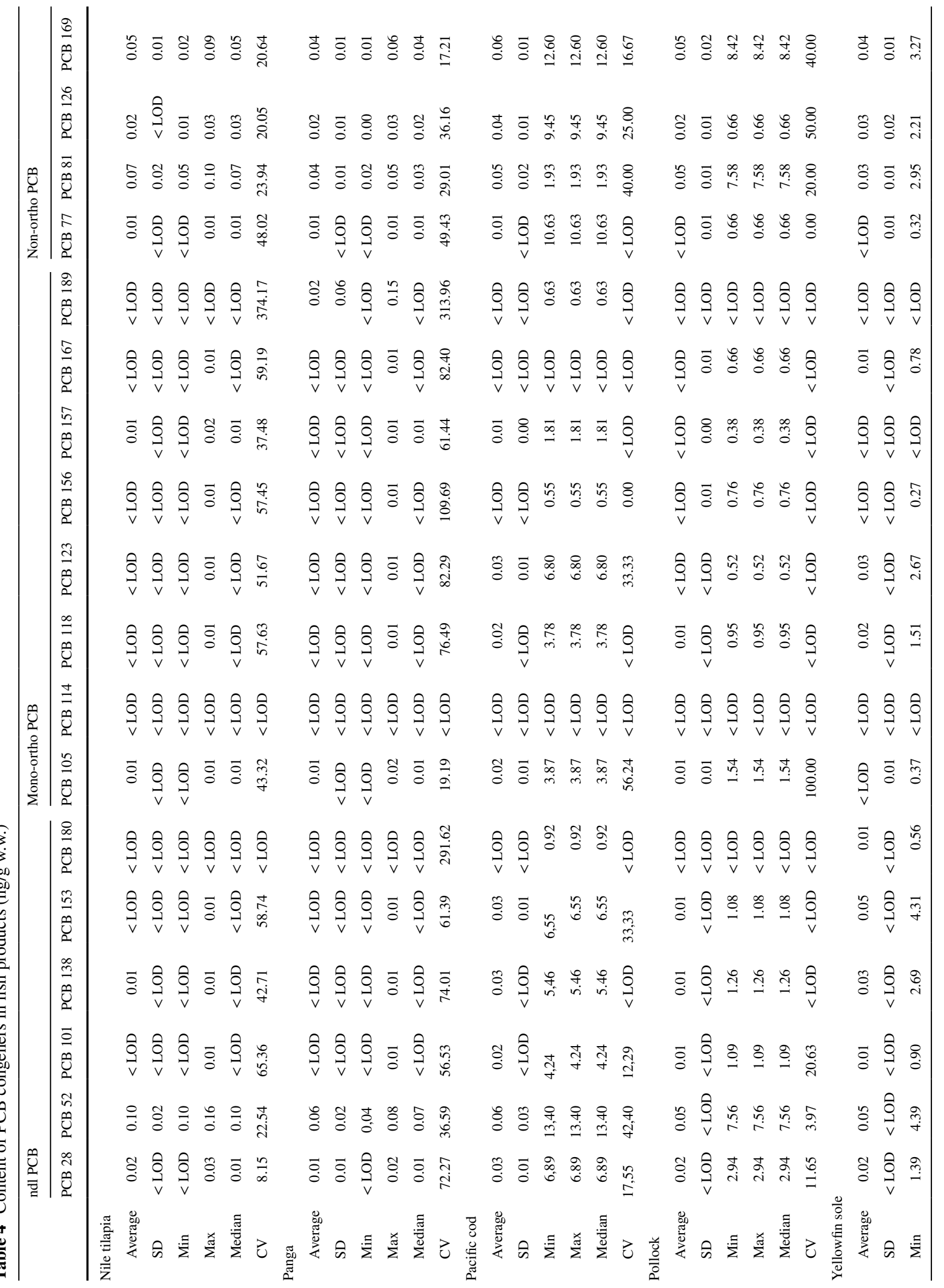




\section{Conclusion}

Consuming fish from contaminated backgrounds can lead to serious consequences for human health. Species differences, origin, or breeding environment can have a significant impact on the final composition of fish meat. Fish fillets originating from imports from China and Vietnam were considered.

The results of this study indicated that although almost all OCPs were detected in all fish fillets tested, the HQ was much lower than 1.0, ranging from 0.003 to 0.013. On the other hand, although almost all PCBs were also detected in the fish tested, the estimated WI was lower than the TWI at $43-53 \%$ of TWI. These results showed that the consumption of imported fish in Poland did not pose a threat to human health. However, the estimated weekly intake values obtained in the present study were about three times higher than the TWI values set by EFSA in 2018. This raises concerns regarding consumer health risks.

The concentrations of OCPs and PCBs in fish products vary depending on fish species; these are associated with different genetic factors, metabolic pathways, and lipid contents. An important factor influencing the level of these compounds in the meat of the fish is the type of feed used to feed farmed fish.

However, processed fish products were analyzed in the current study; therefore, despite the commonly known accumulation properties of organochlorine xenobiotics in adipose tissues, low correlations between the content of these compounds and the fish product lipids were observed. We believe that the reason for this was the glaze, which comprised up to $30 \%$ of the weight of the finished product. Additionally, various additives used in the fish product glazes could also have influenced the results.

Acknowledgement The authors are grateful to Dr. Sławomir Keszka for help in collecting the research material and for consultations.

Open access This article is licensed under a Creative Commons Attribution 4.0 International License, which permits use, sharing, adaptation, distribution and reproduction in any medium or format, as long as you give appropriate credit to the original author(s) and the source, provide a link to the Creative Commons licence, and indicate if changes were made. The images or other third party material in this article are included in the article's Creative Commons licence, unless indicated otherwise in a credit line to the material. If material is not 
Table 5 Concentrations of PCBs, DDTs, HCHs, and HCB in edible fish from different regions all over the world

\begin{tabular}{llllll}
\hline Sample site & $\Sigma$ PCBs & $\Sigma$ DDTs & $\Sigma$ HCHs & HCB & References \\
\hline Shantou Harbor, China & 1.73 & 19.07 & 2.21 & 0.30 & Shi et al. (2013) \\
Haimen Bay, China & 14.91 & 11.00 & 2.63 & 0.15 & Shi et al. (2013) \\
Guiyu, China & 17.3 & - & - & - & Xing et al. (2009) \\
Taizhou, China & 384.5 & - & - & - & Xing et al. (2010) \\
Dalian, China & $1.11-8.04$ & 32.82 & 1.17 & 0.38 & Yang et al. (2006) \\
Tianjin, China & $1.26-5.60$ & 8.05 & 0.43 & 0.30 & Yang et al. (2006) \\
Shanghai, China & $0.83-11.4$ & 19.83 & 0.5 & 0.44 & Yang et al. (2006) \\
Pearl River Estuary, China & - & 80 & 0.20 & - & Guo et al. (2008) \\
Daya Bay, China & - & 40 & 0.26 & - & Guo et al. (2008) \\
Korea & 23 & 8.96 & 0.94 & 0.32 & Yim et al. (2005) \\
Australia & 55 & 22 & 0.34 & 4.20 & Kannan et al. (1995) \\
Spain & - & 2 & 0.6 & 0.1 & Lázaro et al. (1996) \\
\hline
\end{tabular}

Fig. 2 Lifetime average daily dose (LADD) and HQ (Hazard Quotient) values for fish products tested. a-arithmetic mean with standard deviation

Fig. 3 TEQ and WI assessment values in fish products. a-arithmetic mean with standard deviation. *Based on fish consumption of $12.48 \mathrm{~kg} /$ person (34.19 g/day/person) (Hryszko, 2018). TWI ${ }^{1}$ according to EFSA 2015. TWI $^{2}$ — set by EFSA 2018

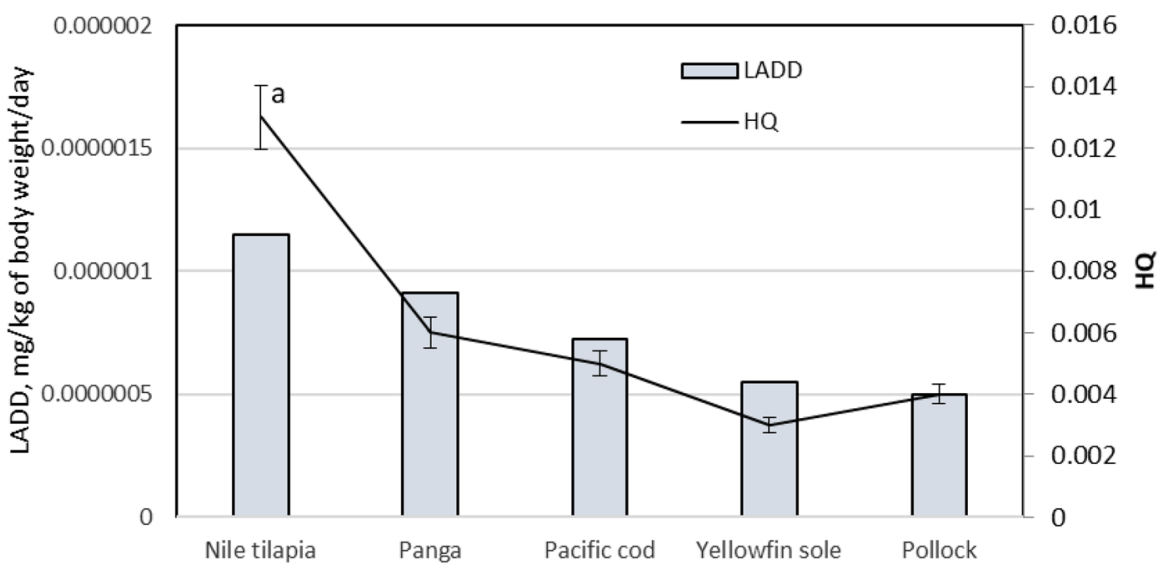

a - arithmetic mean with standard deviation

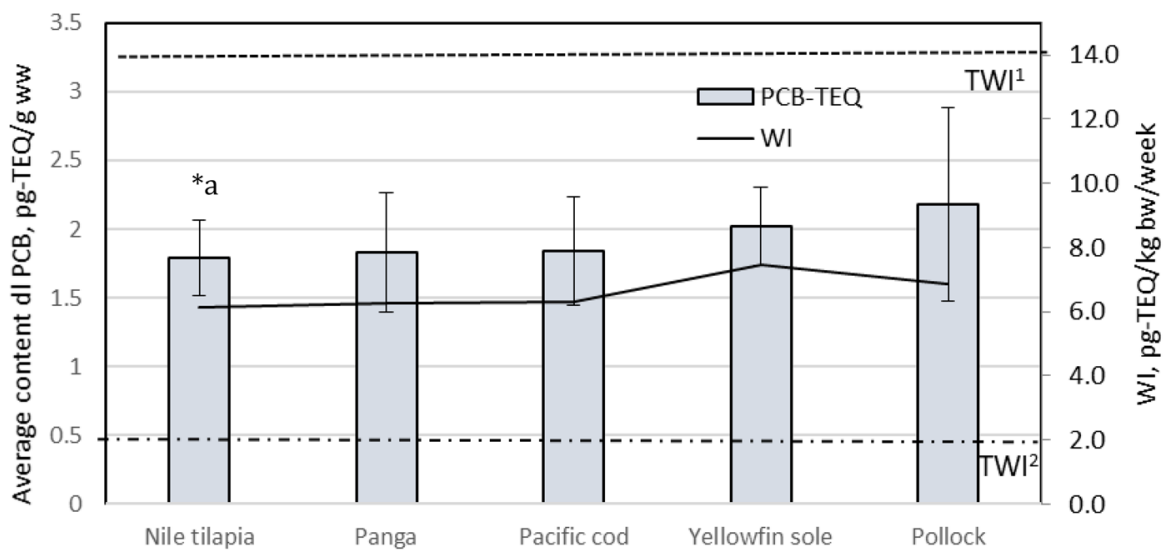

a - arithmetic mean with standard deviation

*Based on fish consumption of $12.48 \mathrm{~kg} /$ person (34.19 g/day/person) (Hryszko, 2018).

TWI ${ }^{1}$ - according to EFSA 2015

$\mathrm{TWI}^{2}$ - set by EFSA 2018 
Table 6 Supplement. Average consumption of different fish species per capita in Poland (Hryszko, 2014, 2019)

\begin{tabular}{llllllllll}
\hline Genre & $\begin{array}{l}2010 \\
\text { per capita in Poland (kg fresh weight) }\end{array}$ & 2011 & 2012 & 2013 & 2015 & 2016 & 2017 & 2018 & $2019^{\mathrm{a}}$ \\
\hline Nile tilapia & 0.49 & 0.34 & 0.31 & - & - & - & 0.30 & & \\
Panga & 1.47 & 1.21 & 0.89 & 0.81 & 0.55 & 0.49 & 0.50 & 0.29 & 0.30 \\
Pollock & 2.76 & 3.04 & 2.60 & 2.68 & 2.28 & 2.21 & 2.21 & 2.21 & 2.05 \\
Pacific cod & 0.42 & 0.65 & 0.83 & 0.85 & 1.22 & 1.11 & 1.04 & 1.00 & 0.85 \\
\hline
\end{tabular}

${ }^{\mathrm{a}}$ Estimated value included in the article's Creative Commons licence and your intended use is not permitted by statutory regulation or exceeds the permitted use, you will need to obtain permission directly from the copyright holder. To view a copy of this licence, visit http://creativecommons.org/licenses/by/4.0/.

\section{References}

Ahmed, M. N., Sinha, S. N., Vemula, S. R., Sivaperumal, P., Vasudev, K., Ashu, S., et al. (2016). Accumulation of polychlorinated biphenyls in fish and assessment of dietary exposure: A study in Hyderabad City. India. Environmental Monitoring and Assessment, 188, 94.

Alcock, R. E., Behnisch, P. A., Jones, K. C., \& Hagenmaier, H. (1998). Dioxin-like PCBs in the environments human exposure and the significance of sources. Chemosphere, 37, 1457-1472.

Barr, D. B., Bishop, A., \& Needham, L. L. (2007). Concentrations of xenobiotic chemicals in the maternalfetal unit. Reproductive Toxicology, 23, 260-266.

Bell, J. G., Waagbø, R. (2008). Safe and nutritious aquaculture produce: Benefits and risks of alternative sustainable aquafeeds. Agriculture, Ecosystems \& Environment, 185-225.

Chang, G. R. (2018). Persistent organochlorine pesticides in aquatic environments and fishes in Taiwan and their risk assessment. Environmental Science and Pollution Research, 5, 7699-7708.

Commission Regulation. (2011). (EU) No 1259/2011 of 2 December 2011 amending Regulation (EC) No 1881/2006 as regards maximum levels of dioxins, dioxin-like PCBs, and non-dioxin-like PCBs in foodstuffs.

Commission Directive 2002/63/EC of 11 July 2002 establishing Community methods of sampling for the official control of pesticide residues in and on products of plant and animal origin and repealing Directive 79/700/ EEC (Text with EEA relevance).

Cui, L., Ge, J., Zhu, Y., Yang, Y., \& Wang, J. (2015). Concentrations, bioaccumulation, and human health risk assessment of organochlorine pesticides and heavy metals in edible fish from Wuhan, China. Environmental Science and Pollution Research (international), 22, 15866-15879.

Deribe, E., Rosseland, B. O., Borgstrøm, R., Salbu, B., Gebremariam, Z., Dadebo, E., et al. (2014). Organochlorine pesticides and polychlorinated biphenyls in fish from Lake Awassa in the Ethiopian Rift Valley: human health risks.
Bulletin of Environmental Contamination and Toxicology, 93, 238-244.

Ding, S., Dong, F., Wang, B., Chen, S., Zhang, L., Chen, M., et al. (2015). Polychlorinated biphenyls and organochlorine pesticides in atmospheric particulate matter of Northern China: Distribution, sources, and risk assessment. Environmental Science and Pollution Research, 22, 17171-17181.

EFSA (European Food Safety Authority). (2005). Opinion of the scientific panel on contaminants in the food chain on a request from the commission related to the presence of non-dioxin-like polychlorinated biphenyls (PCB) in feed and food. (question N_EFSA-Q-2003-114). Adopted on 8 November 2005. Available at http://www.efsa.europa.eu/ en/scdocs/scodc/284.htm (accessed Sep 2016).

EFSA. (2015). Scientific statement on the health-based guidance values for dioxins and dioxin-like PCBs. https://doi. org/10.2903/j.efsa.2015.4124.

EFSA (European Food Safety Authority). (2018). Risk for animal and human health related to the presence of dioxins and dioxin-like PCBs in feed and food. EFSA J.16 (11): 1-331. https://doi.org/10.2903/j.efsa.2018.5333.

FAO. (2018). The state of world fisheries and aquaculture 2018-Meeting the sustainable development goals. Rome. Licence: CC BY-NC-SA 3.0 IGO.

Faroon, O., \& Ruiz, P. (2016). Polychlorinated biphenyls: New evidence from the last decade. Toxicology and Industrial Health, 32(11), 1825-1847. https://doi.org/10.1177/ 0748233715587849.

Gregoraszczuk, E. L., Grochowalski, A., Chrzaszcz, R., \& Wegiel, M. (2003). Congener-specific accumulation of polychlorinated biphenyls in ovarian follicular wall follows repeated exposure to PCB 126 and PCB 153. Comparison of tissue levels of PCBs and biological changes. Chemosphere, 50, 481-488.

Guo, W., Pan, B., Sakkiah, S., Yavas, G., Ge, W., Zou, W., et al. (2019). Persistent organic pollutants in food: Contamination sources, health effects and detection methods. International Journal of Environmental Research and Public Health, 16(22), 4361. https://doi.org/10.3390/ijerph16224361.

Guo, L., Qiu, Y., Zhang, G., Zheng, G. J., Lam, P. K., Li, X. (2008). Levels and bioaccumulation of organochlorine pesticides (OCPs) and polybrominated diphenyl ethers (PBDEs) in fishes from the Pearl River estuary and Daya Bay, South China. Environmental pollution (Barking, Essex: 1987), 152(3), 604-611. https://doi.org/10.1016/j. envpol.2007.06.067 
Hryszko, K. (2018). Agricultural Market. Analysis. Trends. Assessment. Institute of Agricultural and Food Economics, National Research Institute 3, 65-70. (ISSN 0867-8545).

Hryszko, K. (2014). Spożycie ryb i owoców morza oraz ich przetworów. Rynek ryb, stan i perspektywy, 22, 26-30.

Hryszko, K. (2019). Spożycie ryb i owoców morza oraz ich przetworów. Rynek ryb, stan i perspektywy, 30, 29-32.

Huang, F., Li, Z., Zhang, C., Habumugisha, T., Liu, F., \& Luo, X. (2019). Pesticides in the typical agricultural groundwater in Songnen plain, northeast China: Occurrence, spatial distribution and health risks. Environmental Geochemistry and Health, 41, 2681-2695.

IARC/WHO. (2016). Monographs on the evaluation of carcinogenic risk to humans. 2016, 107.

Kannan, K., Tanabe, S., \& Tatsukawa, R. (1995). Geographical distribution and accumulation features of organochlorine residues in fish in tropical Asia and Oceania. Environmental science \& technology, 29(10), 2673-2683. https://doi.org/10.1021/es00010a032.

Lagalante, A. F., Oswald, T. D., \& Calvosa, F. C. (2009). Polybrominated diphenyl ether (PBDE) levels in dust from previously owned automobiles at United States dealerships. Environment International, 35, 539-544.

Lauby-Secretan, B., Loomis, D., Grosse, Y., El Ghissassi, F., Bouvard, V., Benbrahim-Tallaa, L., Guha, N., Baan, R., Mattock, H., Straif, K. (2013). WHO International Agency for Research on Cancer. Carcinogenicity of polychlorinated biphenyls and polybrominated biphenyls. Lancet Oncology, 14(4), 287-288. https://doi.org/10.1016/ S1470-2045(13)70104-9.

Lázaro, R., Herrera, A., Ariño, A., Conchello, A. M., \& Bayarri, S. (1996). Organochlorine pesticide residues in total diet samples from Aragón (Northeastern Spain). Journal of Agricultural and Food Chemistry, 44, 2742-2747.

Ludewig, G., Lehmann, L., Esch, H., \& Robertson, L. W. (2008). Metabolic activation of PCBs to carcinogens in vivo. A review. Environmental Toxicology and Pharmacology, 25, 241-246.

Łuszczek-Trojnar E., Błoniarz P., Winiarski B., Drag-Kozak E., Popek W. (2015). Porównanie koncentracji kadmu, cynku, manganu i niklu w filetach wybranych gatunków ryb konsumpcyjnych. Roczniki Naukowe Polskiego Towarzystwa Zootechnicznego, 11, 75-84. [Łuszczek-Trojnar E., Błoniarz P., Winiarski B., Drag-Kozak E., Popek W., 2015. Comparison of cadmium, zinc, manganese, and nickel concentrations in fillets of selected species of food fish. Scientific Annals of the Polish Society of Animal Production, $11,75-84$.

Mamun, H. A., Islam, S., Hossain, A., Tokumura, M., \& Masunaga, S. (2019). Polychlorinated biphenyls (PCBs) in commonly consumed seafood from the coastal area of Bangladesh: occurrence, distribution, and human health implications. Environmental Science and Pollution Research, 26, 1355-1369.

Mathew, S., Raman, M., Kalarikkathara, P. M., Rajan, D. P. (2019). Fish and fishery products: quality indices. Springer Singapore, 63-144.

OECD, FAO. (2017). OECD-FAO Agricultural Outlook 20172026. OECD Publishing, Paris. https://doi.org/10.1787/ agr_outlook-2017-en.
Salem, N. M., Ahmad, R., \& Estaitieh, H. (2009). Organochlorine pesticide residues in dairy products in Jordan. Chemosphere, 77, 673-678.

Shah, S. N., Khan, A. J., Nawaz, S., Ismail, M., Khan, K., \& Khan, M. H. (2015). Kinetic and mechanism investigation on the gamma irradiation induced degradation of endosulfan sulfate. Chemosphere, 121, 18-25.

Shi, J., Li, Y., Liang, H., Zheng, G. J., Wu, Y., \& Liu, W. (2013). OCPs and PCBs in marine edible fish and human health risk assessment in the eastern Guangdong, China. Archives of environmental contamination and toxicology, 64(4), 632-642. https://doi.org/10.1007/s00244-012-9862-4.

Stockholm Convention 2018. Secretariat of the Stockholm Convention, Geneva 2018. http://www.pops.int/TheConvention/ Overview/TextoftheConvention/tabid/2232/Default. aspx Accessed Jan 142019.

Tomza-Marciniak, A., Pilarczyk, B., Witczak, A., Rząd, I., \& Pilarczyk, R. (2019). PCB residues in the tissues of sea ducks wintering on the south coast of the Baltic Sea, Poland. Environmental Science and Pollution Research, 26, 11300-11313.

Törnkvist, A., Glynn, A., Aune, M., \& Darnerud, P. O. (2011). PCDD/F, PCB, PBDE, HBCD and chlorinated pesticides in a Swedish market basket from 2005-Levels and dietary intake estimations. Chemosphere, 83, 193-199.

Witczak, A., \& Ciereszko, A. (2006). The effect of smoking process on changes in the content of selected non-ortho and mono-ortho PCB congeners in mackerel slices. Journal of Agricultural and Food Chemistry, 54, 5664-5671.

Walczak, M., \& Reichert, M. (2016). Characteristics of selected bioaccumulative substances and their impact on fish health. Journal of Veterinary Research, 60(4), 473480. https://doi.org/10.1515/jvetres-2016-0070.

Witczak, A. (2013). Studium obecności kongenerów PCB w mleku i produktach mleczarskich w aspekcie ryzyka zdrowotnego oraz wpływu procesu technologicznego na poziom tych związków [in Polish - Study of PCB congeners in milk and dairy products in relation to health hazards and the influence of technological process on the levels of these compounds]. Wydawnictwo Uczelniane Zachodniopomorskiego Uniwersytetu Technologicznego w Szczecinie, Szczecin, 2013. ISBN 978-83-7663-144-8.

Witczak, A., \& Abdel-Gawad, H. (2014). Assessment of health risk from organochlorine pesticides residues in high-fat spreadable foods produced in Poland. Journal of Environmental Science and Health, 49, 917-928.

World Aquaculture. (2010). FAO Fisheries and Aquaculture Department. Technical Paper. No. 500/1. Rome, FAO. 2011. 105 pp.

Xing, G. H., Chan, J. K., Leung, A. O., Wu, S. C., \& Wong, M. H. (2009). Environmental impact and human exposure to PCBs in Guiyu, an electronic waste recycling site in China. Environment international, 35(1), 76-82. https:// doi.org/10.1016/j.envint.2008.07.025.

Xing, G. H., Wu, S. C., \& Wong, M. H. (2010). Dietary exposure to PCBs based on food consumption survey and food basket analysis at Taizhou, China-The world's major site for recycling transformers. Chemosphere, 81(10), 1239-1244. 
Yang, N., Matsuda, M., Kawano, M., \& Wakimoto, T. (2006). PCBs and organochlorine pesticides (OCPs) in edible fish and shellfish from China. Chemosphere, 63(8), 1342-1352. https://doi.org/10.1016/j.chemosphere.2005.09.029.

Yim, U. H., Hong, S. H., Shim, W. J., \& Oh, J. R. (2005). Levels of persistent organochlorine contaminants in fish from Korea and their potential health risk. Archives of environmental contamination and toxicology, 48(3), 358366. https://doi.org/10.1007/s00244-004-0085-1.

Zeng, Y. H., Luo, X. J., Zheng, X. B., Tang, B., Wu, J. P., \& Mai, B. X. (2014). Species-specific bioaccumulation of halogenated organic pollutants and their metabolites in fish serum from an e-waste site, south China. Archives of Environmental Contamination and Toxicology, 67, 348-357.

Publisher's Note Springer Nature remains neutral with regard to jurisdictional claims in published maps and institutional affiliations. 